\title{
ГЛОБАЛНЕ ИКОНЕ КАО СРЕДСТВО КОМУНИКАЦИЈЕ У КУЛТУРНОМ ТУРИЗМУ
}

\author{
Зоран Радосављевић ${ }^{1}$, Ана Ланговић Милићевић ${ }^{2}$
}

\begin{abstract}
Сажетак
Глобализација је незаобилазна појава која ствара свет без граница, олакшавајући комуникацију и интеракцију различитих култура. У већим центрима, у којима се економски процеси одвијају, чешће долази до контаката и прихватања различитих култура. У урбаним срединама, интеркултуралност добијапредностнадмултикултуром.Утомпроцесуглобализације, национални музеји проналазе начине да препознају, прикажу и интерпретирају савремене сложености идентитета. Културни туризам постаје битна грана глобалне привреде, а музеји, преко глобалних икона, бележе највећи раст. Глобалне иконе, у овом случају, могу се посматрати као средство интеркултуралне комуникације.
\end{abstract}

Кључне речи: глобализација, културни туризам, глобалне иконе, интеркултурална комуникација.

\section{GLOBAL ICONS AS A MEANS OF COMMUNICATION IN CULTURAL TOURISM}

\begin{abstract}
Globalization is an unavoidable phenomenon that creates a world without borders, facilitating communication and interaction among different cultures. In larger centers, where economic processes take place, contacts and acceptance of different cultures occurs more often. In urban areas, interculturality gain an advantage over multicultural . In that process of globalization, national museums

\footnotetext{
1 Универзитет у Крагујевцу, Факултет за хотелијерство и туризам, Врњачка Бања, e-mail: zoran.rad@mts.rs

2 Универзитет у Крагујевцу, Факултет за хотелијерство и туризам, Врњачка Бања, e-mail: ana.langovic@kg.ac.rs
} 
are beginning to recognize, display, and interpret the contemporary complexities of identity. Cultural tourism is becoming an important part of global economy, the museums, through global icons, are recording the greatest growth of all times. Global icons, in this case, can be seen as a means of intercultural communication.

Keywords: globalization, cultural tourism, global icons, intercultural communication.

\section{УВОД}

У глобалном свету јединствених вредности и драматичних економских, политичких и друштвених промена, туризам постаје спона за друштвене и културне контакте, комуникацију и културну размену. Глобализација је донела бројне користи туризму и допринела његовом развоју и бржем ширењу. Како глобализација утиче на "укидање граница" између држава, повећава се број људи који се укључују у туристичка путовања, јер све дестинације постају приступачне.

Туризам је имао користи од глобализације следећи глобалне принципе друштвено-економског, еколошког и културно-одрживог развоја, што доприноси побољшању света као места у којем се живи и ради (Reisinger, 2009).

Културне промене, које настају на глобалном тржишту, утичу на промене култура локалних заједница, које су носиоци културног туризма. Експлоатација културне баштине, као потрошачке туристичке атракције, у свету глобалних комуникација, проузроковала је мешање култура на свим нивоима.

Један од резултата глобализације је концентрација економских интеракција у урбаним центрима (Tanahashi T. K., 2008). Дакле, експанзија економских интеракција доводи више људи у велике центре. Напредак у глобализацији настоји да убрза премештање људи и пословања у урбану средину. У таквим срединама, интеркултуралност добија предност над мултикултуром. Уместо различитих културних групација, формира се једна, на коју утичу различите културе. Та нова култура се ослања на субкултуре 20. века, али и на неке уметничке правце из ранијих периода.

Циљ овога рада је да покаже који су то културни потенцијали за развој туризма у глобалном начину пословања, кроз примере урбаних средина Париза, Санкт Петербурга и Барселоне.

Хипотеза је да глобализација и интеркултурална комуникација утичу на развој културног туризма у урбаним срединама. 
Истраживање треба да докаже да само одређени сегменти културе, кроз глобалне иконе, повећавају посећеност.

Метода примењена у овом раду је компарација студија случаја за град Барселону и музеје Лувр и Ермитаж.

\section{Преглед литературе}

У уобичајеном смислу, глобализација значи да глобална веза расте и људски живот почиње да се развија на глобалном нивоу (Sjursen, 2000.). Напредак у транспортним и комуникацијским технологијама је основа глобализације. Напредак транспорта промовише глобализацију људи и материјалних производа, а унапређење комуникације промовише глобализацију менталних производа (Featherstone, 2011.). У данашње време глобалне комуникације, напредак транспорта и светски тржни центри, у времену глобалнихсела, чине да често заборавимо колико су велике и дубоке културне разлике. Западњаци уопште, а посебно Американци, брзо закључују да, зато што људи из других делова света такође носе фармерке, слушају популарну музику, једу у Мек Доналдсу и пију Кока-колу, такође прихватају западну културу (Hill, 2003).

Све више људи има могућност да путује у иностранство и тако доживе стране културе и њихово наслеђе. Глобализација је феномен који не мења само изглед света већ и поглед на свет-прелазак са посматрања мултукултурног света на интеркултурни тј. уважавање окружења, разумевање интеркултурности и развој културне свести, знања и нових компетенција (Ланговић-Милићевић, 2014).

Појава глобализације довела је до честих културолошких размена, истовремено промовишући комуникацију, разумевање и поштовање међу свим ентичким групама у свету (Hietala, 2012).

Међутим, није то тако једноставно, нарочито у срединама изван главних глобалних центара, јер “поштовање не значи и прихватање"(Tanahashi T.K.). У већим центрима у којима се одвијају економски процеси, чешће долази до прихватања различитих култура, најчешће преко хране, музике и глобалних икона. Најчешће глобалне иконе су уметници (Да Винчи, Пикасо, Ворхол, Лорка...), али и политичари који су довели до великих промена у друштву, ван граница своје земље (Че Гевара, Лењин, Хајле Саласије...).

Изазов за европске националне музеје је како препознати, приказати и интерпретирати савремене сложености идентитета, култура и историја на начин који је разумљив, привлачан и резонантан са савременом музејском 
публиком. То је посебно зато што европска музејска публика може да буде све више интерно хетерогена, диференцирана и, у неким случајевима, космополитска у смислу њихових вредности, искустава и очекивања управо због истих притисака који произлазе из садашњих облика глобализације и постнационализма (Mason, 2013).

Нијман тврди да постоји процес културне глобализације који тече паралелно са економском глобализацијом. Културна глобализација подразумева: убрзање размене културних симбола међу људима широм света, до те мере да доводи до промене у локалним популарним културама и индетитетима (Nijman, 1999). Ова размена културних симбола је подржана проширењем одређених система потрошње ( као што је културни туризам) и убрзана масовном комуникацијом (нпр. Интернет), као и масовним туризмом. Таква потрошња укључује не само материјална добра, већ и идеје, вредности и информације или другим речима културу (Richards, 2007).

Упркос могућностима виртуелног, престижа и слава музеја су протеклих тридесет година подупрте феноменом међународних изложби блокбастера. Чаробна моћ познатих објеката да мобилишу огромну публику која плаћа улазницу на специјалне изложбе "подмазује точкове" глобалне презентације, која се састоји углавном од високих уметничких дела и других древних или вредних објеката (Young, 1999).

Музеји уметности и уметничке поставке у класичним музејима бележе повећање посетилаца сваке године. Данашњи музеји су као некада катедрале; отворене за људе свих генерација и свих друштвених слојева који желе да искусе јединственост коју пружају уметничка дела у свету све веће стандардизације (www.artprice.com).

Музеј светске културе у Гетеборгу (Шведска), усваја експлицитно космополитску, постколонијалну и глобалистичку филозофску позицију у својим институционалним изјавама: У дијалогу са друштвом у којем постоји, Музеј светске културе тежи да служи као место где ће осетљива, интелектуална искуства омогућити људима да се осећају угодно у земљи и иностранству, верујући и преузимајући одговорност за заједничку глобалну будућност у свету који се стално мења (www.archive.org). Музеј жели да буде арена за дискусију и рефлексију у којој ће се чути многи и различити гласови, где се могу решити контроверзне и конфликтне теме, као и место где се људи могу осећати код куће преко граница. (www.archive.org).

\section{Барселона}

Барселона је главни град Каталоније и други по величини у Шпанији. Налази се на обалама Медитерана на Североистоку Шпаније. Окружена 
је морем на истоку, планинским венцем Сијера де Кољсерола на западу и рекама Лобрегат и Бесос.

Мада се до деведесетих година прошлог века туризам заснивао на крстарењима, од којег су остваривали значајне приходе, тек последњих тридесетак година број туриста се значајно повећао. Тако је број туриста у хотелима порастао од 1,8 милиона у 1990. години, на рекордних 9,07 милиона у 2016. години. Они су оставили 8,9 милијарди долара (www.statista.com). Занимљиво је да је чак трећина (33,9\%) посетилаца узраста између 25-34 године (www.statista.com).

Слика 1. Број туриста у Барселони од 1990. до 2017. године

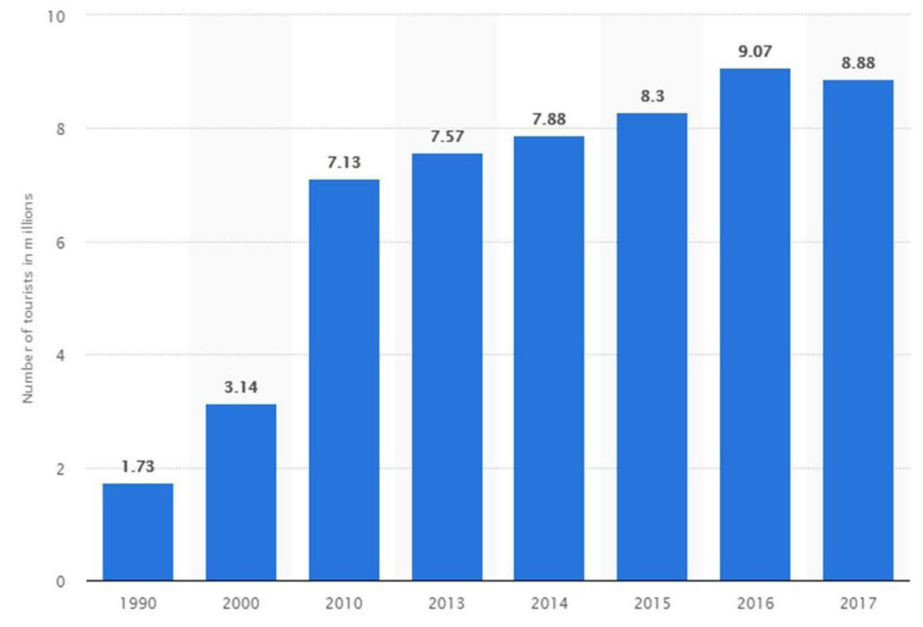

Извор: www.statista.com

Према Бенаку и Алберту, кључни елемент у повећању броја посетилаца је слика града. Слика постаје облик визуелног капитала који се развија и користи у области интер-урбане конкуренције (Benach \& Albert, 2004)

У данашње време, велики градови такмиче се за интернационални престиж у области културног туризма. Сваки од њих развија своју стратегију привлачења капитала, а све из разлога да баш они буду културна престоница Европе. Опште је прихваћен став да, у оквиру тог такмичења између градова, производња урбаних слика има пресудни значај (Monculs, 2000).

Барселона је имала корист од оживљавања локалне, каталонске културе, али је истовремено локална култура глобализована (Richards, 2007).

Иконе каталонске културе, као што су Гауди, Миро и Дали су коришћени за повезивање локалне културе са глобалним културним интересима туриста. Далијев музеј је удаљен од центра Барселоне и налази се у родном граду 
уметника, у Фигуерасу. Музеј је забележио посету од 1.444 .853 посетиоца у 2016. години (www.salvador-dali.org/en/services/press/news/359/the-dalimuseums-receive-1-4-million-visitors).

Начин на који је Гауди претворен у глобалну икону града, подсећа на процес комодификације и тематизације који су уско повезани са америчким градовима (Monclus, 2003).

Базилика La Sagrada Familia, коју је пројектовао Антонио Гауди, годишње обиђе око 3,5 милина посетилаца, док његове објекте у граду, још милион. Пикасов музеј и Фондација Миро имају годишњу посету од око милион туриста (www.catalannews.com). Пикасов музеј се налази у Барселони, у граду где је његова породица живела у периоду од 1895-1904. године.Музеј је смештен у неколико готичких кућа у старом делу Барселоне званом Ел Борн. (https://sites.google.com/site/barselonaturizam/muzeji-grada).

Од 2007. године ради музеј Гауди центар у градићу Реус, у близини Барселоне.

Дакле, можемо рећи да је повећање броја туриста, у последњих тридесет година, директно повезано са глобализацијом, кроз глобалне иконе. Гауди, Миро и Пикасо чине 50\% укупних културних посета центру Барселоне (Richards, 2007).

\section{Ермитаж}

Санкт Петербург је други најпосећенији град у Русији и често називан културном престоницом. По подацима сајта www.guidetopetersburg.com у 2018. години било је 8,2 милиона туриста, што је за око 15\% више него у 2017. години. Главни разлог повећања је Светско првенство у фудбалу. Према подацима истог извора, половина туриста били су странци.

Санкт Петербург је град историјских знаменитости, музеја и уметничких галерија. Велики број позоришта и креативних група раде у граду.

Град је изграђен на 44 острва нареци Неви. Поред туристичких атракција, као што су вожња бродићима дуж канала и реке, крстарење крузерима, највеће интересовање привлаче музеји Ермитаж, Катедрала Св. Исака и област Петерхоф.

Катедрала Св. Исак је препознатљива по својој неокласичној куполи, која привуче око четири милиона посетилаца годишње.

Петерхоф, у чији музејски комплекс улазе Стрелна и Ломоносов, у 2018. години био је најпосећенији музеј са 5,5 милиона туриста. Главну атракцију у овој области представљају фонтане и паркови правих и строгих 
геометријских облика и линија. Такође, лепоту Петерхофачини Гранд Палас и друге грађевине тог периода.

Музеј Ермитаж један је од највећих и најпрестижнијих музеја на свету. Према часопису Национална Географија, Ермитаж се налази на четвртом месту најбољих музеја (www.nationalgeographic.com). Посета у 2017. години била је око 4,3 милиона, у односу на 3,7 милиона у 2015. години (www. hermitagemuseum.org). Близу половине туриста чине странци. Музеј је један од најстаријих на свету. Основан је 1764. године, када је царица Катарина Велика добила колекцију радова од немачког трговца Јохана Ернста Гацовског (Allen et al., 2015). Од 1852. године отворен је за јавност.

Збирка је изложена у шест зграда на обали Неве, с тим што је главна зграда Зимски дворац, који је некада био резиденција руских царева (www. sr.wikipedia.org). Најзначајнија збирка овог музеја је збирка западноевропских сликара: Микеланђела Буанаротија, Леонарда да Винчија, Рубенса, Ремранта, Винсента Ван Гога, Пабла Пикаса, Анрија Матиса и других.

Од 2015. године, део простора је намењен делима савремене уметности.

На повећану посећеност у 2017. години утицало је обележавање стогодишњице Октобарске револуције. Иако највећу посету музеј Ермитаж бележи у периоду април-новембар (Danielle et al., 2015.), изложбе које су за тематикуималеОктобарскуреволуцијусуинсталиранеупериодуодновембра 2016. године до фебруара 2017. године. Називи изложби су : "Зимска палата и Ермитаж у 1917. - Историја је прављена овде" и "Штампа и Револуција 19171922.." Изложба "Историја је прављена овде" је била најпосећенија у 2017. години - 380.000 посетилаца. Трајала је 58 дана и просечно је имала посету од 6.500 људи. Већина посетилаца (68\%) били су млађи од 35 година, од којих је 59\% било високообразовано. Просечна старост публике била је 32 године (www.hermitagemuseum.org). Изложбена поставка је садржала слике, али и говоре Лењина који, као икона Револуције, је привукао већи број млађих посетилаца.

Ермитаж је отворио филијале у више светских градова. Тако је од локалног музеја, постао глобални бренд. Филијале у Амстердаму, Лас Вегасу, Лос Анђелесу и Ферари су показатељ да глобализација утиче на посећеност у урбаним срединама. Поставка "1917. Романови и Револуција, крај монархије" у филијали у Амстердаму имала је 230.000 посетилаца, од укупно 400.000, колико је забележено 2017. године (www.amsterdamtips.com). 


\section{Лувр}

Лувр је један од највећих и најпознатијих музеја на свету. Налази се на десној обали реке Сене у Паризу. Национални музеј и уметничка галерија Француске се налази на десној страни тврђаве грађене у 12. веку, за време Филипа Августа (www.britannica.com). То је најпосећенији музеј са колекцијом од древних цивилизација до средине 19. века. На темељима тврђаве, Францис I почео је да гради краљевску резиденцију 1546. године. У историји је остао упамћен као велики љубитељ и сакупљач уметничких дела (www.discoverfrance.net). Каснији француски краљеви наставили су градњу, али и прикупљање уметничких дела и артефаката. Нарочито су били познати кардинал Ришеље, који је дела сакупљао за Луја XIII, и кардинал Мазарин за Луја XIV. Године 1793. револуционарна влада је отворила врата музеја за народ. Та година се сматра за почетну у музеологији (Lewis, 2000).

Комплекс грађевине Лувр је осамдесетих и деведесетих година прошлога века рестауриран. Тада је изграђен велики подземни комплекс који је "крунисан контравезном челично-стакленом пирамидом, коју је дизајнирао амерички архитекта И. М. Пеи". Такође, ново крило је дизајнирао Пеи, у којем је смештена колекција европског сликарства, декоративне уметности и исламске уметности, која је касније пресељена у своје крило. Три унутрашња дворишта са стакленим кровом, приказала су француску скулптуру и древна асирска дела (www.britannica.com).

Колекција слика у Лувру једна је од најбогатијих на свету и представља све периоде уметности до 1848. године. Најпознатије уметничко дело изложено у музеју је Да Винчијева слика Мона Лиса (www.sr.wikipedia.org).

У 2018. години Лувр је посетило, рекордних 10,2 милиона посетилаца. То је пораст од скоро $25 \%$ у односу на 2017. годину. Претходни рекорд је 9,7 милиона у 2012. години, у којој је отворено Одељење за исламску уметност и представљена изложба Да Винчија и Рафаела (www.presse.louvre.fr).

Године 2018. поп музичари Beyoncen JAY-Z су снимили видео у простроријама Лувра. Према званичном сајту музеја, број млађих од 30 година, у 2018. години се повећао на преко половине укупног броја посетилаца. Као разлог, претпоставља се да је управо поменути видео (www.presse.louvre.fr).

Из претходног се може закључити да не само имена глобалних икона, као што су Да Винчи, или музичари Beyonceи JAY-Z, већ и њихова дела (Mona Lisa, APES**T) могу утицати на повећање посете.

Од новембра 2017. године ради, као филијала, музеј Лувр у Абу Дабију. Већ у 2018. години музеј је обишло преко милион посетилаца, од којих су преко 60\% били странци (Carvajal, 2018.). Разлог толиком интересовању је бренд музеја, али и поставке слика Да Винчија, Ван Гога, Рембранта и 
других глобалних икона, док поставка “Путеви Арабије; археолошка блага из Саудијске Арабије" је привукла знатно мањи број страних туриста (www. louvreabudhabi.ae).

Мануел Рабате, директор Лувр Абу Даби је истакао:“Као музеј, не славимо само древне културе, већ и савремено стваралаштво из целог света, кроз уметничке форме" (www.louvreabudhabi.ae).

У периоду 2003-2011. године, урађена су три истраживања која су обухватала посетиоце свих узраста и образовања. Истраживање се односило на то колико савремена уметност утиче на посетиоце класичног музеја какав је Лувр. Спроведено је квалитативно истраживање, које је комбиновало вишеструке технике, укључујући посматрање и интервјуе. На 2/3 посетилаца је утицало позитивно. То су високообразовни људи, млађе старосне доби и студенти. (Larcenux, 2016.)

\section{ЗАКЉУЧАК}

Културни туризам је набрже растући сегмент у туризму. Број посета музејима и културним догађајима сваке године је у порасту. Према Светској туристичкој организацији (UNWTO) просечна стопа раста, у последњих пет година, је 20\% (WTO, 2018). Према истом извештају, број културних посета је највише порастао у Америци (130\%), док на Блиском истоку стагнира или бележи пад. Урбане средине бележе пораст туриста који су мотивисани културом и оних који учествују у културним активностима (62\%).

Глобализација представља један од најбитнијих разлога за овај пораст. Реално је очекивати да нестанком или смањењем географских препрека и језичких баријера, дође до интеракције различитих култура. Та интеракција утиче на повећање заинтересованости за друге културе. Некада уметници и научници, који су утицали на настанак и развој националних идентитета, данас су део заједничке светске баштине. У великим центрима, где је глобализација прихваћена као неминовност из које проистичу економске и културне интеракције, интеркултуралност је постала свеприсутна.

Музеји, некада битни за стварање културног идентитета и буђења националне свести, данас трагају за својим идентитетом. Велики национални музеји све више своје поставке прилагођавају потенцијалним посетиоцима. Изложбе које привлаче пажњу нису везане за национални идентитет, већ су окренуте стварању глобалног идентитета, кроз глобалне иконе. Управо студије случаја из овог рада показују да је доминантан правац повећања 
посећености глобализација локалних икона, али и њихова дела. Архитектура, уметност, али и историјски догађаји, који су утицали на промене у друштву, су привлачили велику пажњу јавности. Музеји сада више нису локалне установе које се баве очувањем националног идентитета, већ постају глобални брендови, отварањем својих филијала по свету.

Глобалне иконе повећавају број посетилаца, али и отварају питање, колико стварно тај глобални идентитет има своју одрживост?

\section{ЛИТЕРАТУРА}

1. Allen, D., Rhoden, S., Sakharchuk, E., Ilkevich, S., Sharafanova E. and Pecheritsam, E. (2015). Cultural Tourism, Tourism in Russia: A Management Handbook, Emerald Group Publishing Ltd, New York

2. Benach Rovira, Nuria and Albert Mas, Abel (2004). Barcelona 1979-2004, entre el modelo y elespectaculo. In: Minca, Claudio (ed.) (2004). Lo spettacolodellacitta/The Spectacle of the City. Padova: CEDAM

3. Geoffry L. (2000). Histroty of Museums.

4. www.britannica.com/topic/history-of-museums-398827

5. Doreen C. (2018). Louvre Abu Dhabi Draws One Million People in Debut Year, New York Times, 11.11.2018.

6. Ланговић-Милићевић А. (2014). Стратегијски менаимент и интеркултуралност, Универзитет у Крагујевцу, Факултет за хотелијерство и туризам у Врњачкој Бањи

7. Larceneux F. (2016.) The Reaction of Visitors to Contemporary Art in a Classical Art Institution: A LouvreMuseum Case Study,International Journal of Arts Management 18(2):4-13

8. Mason, R. (2013). National Museums, Globalization, and Postnationalism: Imagining a Cosmopolitan Museology, Museum Worlds: Advances in Research 20131 (1). pp. 40-64, Newcastle University ePrints

9. Monclús, F. J. (2000). Barcelona's planning strategies: from 'Paris of the South' tothe 'Capital of West Mediterranean'. GeoJournal. pp 51- 57

10. Nijman, J. (1999). Cultural globalization and the identity of place: The reconstruction of Amsterdam.Ecumene, Vol. 6: 146-164

11. Reisinger, Y. (2009). International Tourism: Cultures and Behavior. Oxford: Elsevier Richards, G. (2007).Globalisation, localisation and cultural tourism, Destination Revisited: Perspectives on developing and managingtourist areas. Arnhem, ATLAS, pp. 25-34

12. Sjursen, K. (2000). Globalization. Bronx, N.Y.: H.W. Wilson Co., p.32 
13. Tanahashi K.T. (2008). Globalization and Emerging Roles of Cultural Tourism. http:// www.tku.ac.jp/kiyou/contents/administration/260/260_tanahashi.pdf

14. Featherstone, M. (2011). Global culture, London, Sage, p.51

15. Hietala, M. (2012). New Challenges for Urban History: Culture, Networks, Globalization, Culture \& History, Digital Jornal, 1(2), p. 8

16. Hill, C.W.L. (2003). Global Business, second edition, McGraw-Hill Irwin, Boston

17. Young, L. (2007). Globalisation, culture and museums, A Review of Theory,

18. International Journal of Heritage Studies, Vol. 5

19. World Tourism Organization. (2018). Tourism and Culture Synergies, UNWTO, Madrid, DOI: https://doi.org/10.18111/9789284418978

\section{Интернет извори}

1. www.artprice.com/artprice-reports/the-art-market-in-2017/the-art-market-globalization-and-impact-of-the-museum-industry прегледан: 18.08.2020.

2. www.archive.org/details/varldskultur прегледан: 21.08.2020.

3. www.statista.com/statistics/452060/number-of-tourists-in-barcelona-spain/, прегледан: 14.08.2020.

4. www.statista.com/statistics/456906/tourist-distribution-in-barcelona-spain-by-age/, прегледан: 14.08.2020.

5. www.salvador-dali.org/en/services/press/news/359/the-dali-museums-receive1-4-million-visitors прегледан: 03.09.2020.

6. www.catalannews.com/culture/item/catalan-museums-received-21-5-million-visitors-in-2013 прегледан: 14.08.2020.

7. https://sites.google.com/site/barselonaturizam/muzeji-grada прегледан:02.09.2020.

8. www.guidetopetersburg.com/st-petersburg-tourism-statistics-2018/, прегледан: 16.08.2020.

9. www.nationalgeographic.com/travel/top-10/museum-galleries/ прегледан: 16.08.2020.

10. www.hermitage.ru/wps/wcm/connect/ebe6a7d0-e023-4166-bc7a-9d2843c82d7d/ The

11. +State+Hermitage+Museum+Annual+Report+2017.pdf?MOD=AJPERES\&amp;

12. CACHEID=ebe6a7d0-e023-4166-bc7a-9d2843c82d7d прегледан: 16.08.2020.

13. www.amsterdamtips.com/hermitage-amsterdam прегледан: 17.08.2020. 
14. www.britannica.com/topic/Louvre-Museum прегледан: 20.08.2020.

15. www.discoverfrance.net/France/Paris/Museums-Paris/Louvre.shtml, прегледан: 20.08.2020.

16. www.presse.louvre.fr/10-2-million-visitors-to-the-louvre-in-2018/, прегледан: 21.08.2020.

17. www.sh.wikipedia.org/wiki/Barcelona прегледан: 14.08.2020.

18. www.louvreabudhabi.ae/en/pressroom прегледан: 21.08.2020.

Рад је примљен:

24. август 2020.

Received:

August 24, 2020.
Враћен на корекцију:

31. август 2020.

Sent for Revision:

August 31, 2020.
Прихваћен за објављивање:

7. септембар 2020.

Accepted:

September 7, 2020. 